\title{
Self Assessment of Outstanding Teachers Competition Program Using the Malcolm Baldrige Model
}

\author{
Rusi Rusmiati Aliyyah*, Rasmitadila, Megan Asri \\ Humaira \\ Faculty of Teacher Training and Education \\ Universitas Djuanda \\ Bogor, Indonesia \\ *rusi.rusmiati@unida.ac.id, rasmitadila@unida.ac.id, \\ megan.asri@unida.ac.id
}

\author{
Didi Mulyadi \\ Faculty of Management \\ The Graduate School of Economics Pertiwi \\ Bekasi, Indonesia \\ didi.mulyadi@pertiwi.ac.id
}

\author{
Siti Pupu Fauziah, Widyasari, Sri Wahyuni Ulfah \\ Faculty of Teacher Training and Education \\ Universitas Djuanda \\ Bogor, Indonesia
}

sitipupufauziah@unida.ac.id, widyasari@unida.ac.id, sri wahyuniulfah26@gmail.com

\begin{abstract}
The government program is mostly based on the supply model in which the program has already been created, and the following institutions just carry out the program as instructed. This research is aimed to assessing the outstanding competition program using the Malcolm Baldrige model. The model used is the seven model uses in the quality assessment includes; leadership, strategic planning, customer and market focus, measurement, human resource focus, process management, and results. The research concludes that there needs more improvement in the outstanding teacher's competition, especially from a strategic point of view in which the while stakeholders must be aware of how the program is about to run. The program analysis using the Malcolm Baldrige model can be seen as a sound and comprehensive study that will enhance the betterment of the continuity of the program. It will also help relevant parties to focus on improvement and communication efforts in the most critical areas. Also, identify some ideas for improvement and identify opportunities for future program innovation.
\end{abstract}

Keywords—quality education, assessment, primary school

\section{INTRODUCTION}

Outstanding teachers are believed and understood as one of the most important elements in maintaining the quality of Education [1]. The Indonesia Constitution No 14, 2005 states the importance of the quality teachers by one of them providing them with certification. Once one country is done with the teacher's quality, the other tasks are only a while wait to happen. Indonesia, with a population of more than 250 million currently positioned 14th lowest countries in students reading and numeric quality based on the 2018 PISA report numbering 396 out of 489 of the OECD countries [2]. The data confirmed the quality education of Indonesia, and the answer to developing the quality of the teachers is now in urgent need. The questions are; 1) how does the government create a comprehensive and long term model in selecting outstanding teachers so that they will enhance the quality of the graduates; 2) how does the government provide a guarantee to those selected as outstanding teachers candidates including those in private schools. Developing teachers are only seen as a second option compared to these in the industrial or business process in which the measurement of ones that eligible for certain positions shall have a thorough and detail assessment. The assessment popular in the business operation is the Malcolm Baldrige model in which the whole management processes are viewed, valued, and scored based on the performance. A Baldrige self-assessment helps organizations assess whether a sound, balanced, and systematic approach is being developed and deployed to run their organizations. Whether your organization is big or small, and regardless of your industry or sector, you can use the Baldrige Excellence Framework and Criteria to conduct your organization's self-assessment. It provides a way of assessing how well your organization is meeting its goals and goals. Organizations use it to assess their processes and their impact on the outcomes [3].

To survive in this competitive market, commercial organizations must increase their competitive advantage through sustainable improvement [4]. The right and accurate performance indicators can assess the company's success to reflect its competitiveness [5]. Evaluation of business 
performance's superiority is one of the main points in the learning and measurement process, including employee involvement. Thus, carrying out the assessment allows an organization to develop and strengthen the management system and improve its performance. While in the education sector many educators believe that a focus on quality in schools greatly improves teaching, learning, and administration, and Baldrige is particularly trying to address this increase [6]. So it is important to do self-assessment in educational institutions including those engaged in the business sector, including teachers.

Quality awards can increase awareness of performance excellence and competitive opportunities to share successful performance strategies. The Association of Scientists and Japanese Engineers (JUSE) established a Deming prize in 1951 to appreciate the Japanese company for quality improvement excellence. MBNQA is the most commonly used superior framework launched in the United States in 1988. The award can increase awareness about the importance of the quality management system and achieved the objectives set for customer satisfaction [5]. In 1988, the Australian Quality Council (AQC) launched the Australian Business Excellence Award, an award that aims to increase awareness of the company's quality and recognize success in increasing productivity. Another award was the Canadian award introduced by the Ministry of Industry in 1984 and was revised in 1989, taking into account the criteria for Malcolm Baldrige's assessment.

This research is aimed to compare the Malcolm Baldrige model in assessing good corporate governance, especially those in maintaining quality. The model is naturally aimed at assessing the quality of the corporation, but it would be great ideas if the model is tried in the education business or government institutions.

\section{MATERIALS AND METHODS}

This research uses both library research and qualitative descriptive methodology. This type of library research involves some process or step by step in gathering information for writing a paper, making a presentation, completing a project, and describing, analyzing, and evaluating information found in primary sources. By repackaging information, secondary sources make information more accessible [7,8]. Qualitative descriptive research is purely data-derived in that codes are generated from the data in the course of the study. Like other qualitative research approaches, qualitative descriptive studies generally are characterized by simultaneous data collection and analysis [9].

The data were gained through interviews and documentation from related sources. The research participants were schools with outstanding candidates in them, educational regional offices head, principals, and national level outstanding teachers from seven consecutive schools from five provinces In Indonesia which consists of the Rangkasbitung Banten 1 State Elementary School, the Karangpawulang State Elementary
School in West Java, the Psaingan Baro 01 Jakarta Elementary School, the Rejosari 03 Central Java Elementary School, the Muhammadiyah Sapen 1 Yogyakarta Elementary School, the Girimoyo 2 East Java Elementary School and the Elementary School. Negeri Tanjungsekar 03 East Java.

The research was conducted in August 2020 and this research was trying to connect the current practice of the whole process in selecting outstanding teachers with the Malcolm Baldrige Model. It compared all seven criteria model and practices, as shown in Table 1:

TABLE I. Methodology Using the Malcolm BALDRIGE Model [10].

\begin{tabular}{|c|c|c|}
\hline Criteria & $\begin{array}{l}\text { Definition in Malcolm } \\
\text { Baldrige Model }\end{array}$ & $\begin{array}{c}\text { Specific Items in } \\
\text { Outstanding Teachers } \\
\text { Program Competition }\end{array}$ \\
\hline Leadership & $\begin{array}{l}\begin{array}{l}\text { Examine how senior } \\
\text { executives guide }\end{array} \\
\text { organizations and how } \\
\text { they handle their } \\
\text { responsibilities to the } \\
\text { public and practice good } \\
\text { citizenship }\end{array}$ & $\begin{array}{l}\text { How do related education } \\
\text { office leaders guide teachers } \\
\text { candidate, including how } \\
\text { they review teachers' } \\
\text { performance? }\end{array}$ \\
\hline $\begin{array}{l}\text { Strategic } \\
\text { Planning }\end{array}$ & $\begin{array}{l}\text { Examine how the } \\
\text { organization sets the } \\
\text { strategic direction and } \\
\text { determines key action } \\
\text { plans }\end{array}$ & $\begin{array}{lr}\text { How do } & \text { related education } \\
\text { offices } & \text { establish their } \\
\text { strategic } & \text { objectives, } \\
\text { including } & \text { enhancing } \\
\text { outstanding } & \text { teacher } \\
\text { candidates' performance? }\end{array}$ \\
\hline $\begin{array}{l}\text { Customer and } \\
\text { market focus }\end{array}$ & 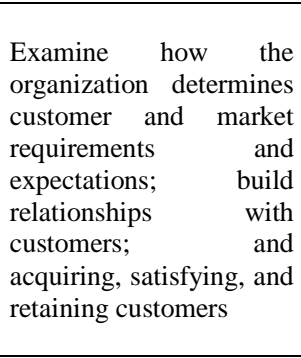 & $\begin{array}{l}\text { How do the relevant } \\
\text { education offices determine } \\
\text { the requirements, } \\
\text { expectations, } \\
\text { preferences of students, } \\
\text { parents, and the education } \\
\text { market to ensure the } \\
\text { continued relevance of } \\
\text { teaching services and } \\
\text { develop new teaching } \\
\text { service opportunities? }\end{array}$ \\
\hline $\begin{array}{l}\text { Measurement, } \\
\text { analysis and } \\
\text { knowledge } \\
\text { management }\end{array}$ & $\begin{array}{l}\text { Check management, } \\
\text { practical use, analysis, } \\
\text { and enhancement of data } \\
\text { and information to } \\
\text { support major } \\
\text { organizational processes } \\
\text { and organizational } \\
\text { performance } \\
\text { management systems. }\end{array}$ & $\begin{array}{l}\text { How can the relevant } \\
\text { education office provide an } \\
\text { effective performance } \\
\text { management system to } \\
\text { measure, analyze, align, and } \\
\text { improve high-achieving } \\
\text { teacher candidates' } \\
\text { performance? }\end{array}$ \\
\hline $\begin{array}{l}\text { Human } \\
\text { resource } \\
\text { focus }\end{array}$ & $\begin{array}{l}\text { xamining how the } \\
\text { organization allows its } \\
\text { workforce to develop its } \\
\text { full potential and how } \\
\text { the workforce is aligned } \\
\text { with organizational goals }\end{array}$ & $\begin{array}{l}\text { How do the relevant } \\
\text { education offices support } \\
\text { the achievement of } \\
\text { outstanding teacher } \\
\text { candidates' overall goals, } \\
\text { including building teacher } \\
\text { knowledge, skills, and } \\
\text { abilities and contributing to } \\
\text { high performance? }\end{array}$ \\
\hline $\begin{array}{c}\text { Process } \\
\text { management }\end{array}$ & $\begin{array}{l}\text { Examine aspects of how } \\
\text { major } \\
\text { production/delivery and } \\
\text { support processes are } \\
\text { designed, managed, and } \\
\text { improved }\end{array}$ & $\begin{array}{l}\text { How do the related } \\
\text { education offices manage } \\
\text { their key processes that lead } \\
\text { to teaching and learning } \\
\text { growth and success? }\end{array}$ \\
\hline
\end{tabular}


Table I. Cont.

\begin{tabular}{|c|c|c|}
\hline Criteria & $\begin{array}{l}\text { Definition in Malcolm } \\
\text { Baldrige Model }\end{array}$ & $\begin{array}{c}\text { Specific Items in } \\
\text { Outstanding Teachers } \\
\text { Program Competition }\end{array}$ \\
\hline $\begin{array}{l}\text { Business } \\
\text { results }\end{array}$ & $\begin{array}{l}\text { We are examining } \\
\text { organizational } \\
\text { performance and } \\
\text { improvement in its key } \\
\text { business areas: customer } \\
\text { satisfaction, financial } \\
\text { and market performance, } \\
\text { human resources, } \\
\text { suppliers, and partners; } \\
\text { operational performance; } \\
\text { and governance and } \\
\text { social responsibility. } \\
\text { This category also } \\
\text { examines how the } \\
\text { organization is } \\
\text { performing against } \\
\text { competitors. }\end{array}$ & $\begin{array}{l}\text { How outstanding teachers } \\
\text { improve human resources } \\
\text { quality as shown in the } \\
\text { Human Development Index } \\
\text { over three years. }\end{array}$ \\
\hline
\end{tabular}

\section{RESULTS}

The result of the research found that the national outstanding teacher's competition, as shown in Table 2, following the seven criteria applied by the Malcolm Baldrige model. The conclusion was based on numbers of responses from Agree (A), Strongly Agree (SA) criteria as successful while the Strongly disagree (SD), Disagree (D), and Undecided (U) were categorized as not successful.

TABLE II. OVERALL RESUlT OF OUTSTANDING TEACHERS CRITERIA UNDERSTANDING

\begin{tabular}{|l|l|l|l|l|l|}
\hline \multicolumn{1}{|c|}{ Components } & SD & D & U & A & SA \\
\hline Leadership & 0 & 10 & 16 & 50 & 24 \\
\hline Strategic Planning & 0 & 34 & 32 & 28 & 6 \\
\hline Customer & 0 & 3 & 26 & 60 & 11 \\
\hline Measurement & 0 & 0 & 26 & 63 & 11 \\
\hline Human Resources & 2 & 5 & 17 & 62 & 14 \\
\hline Operation & 4 & 11 & 22 & 46 & 17 \\
\hline Result & 4 & 10 & 31 & 41 & 14 \\
\hline OVERALL & 1 & 11 & 24 & 50 & 14 \\
\hline & $36 \%$ & $64 \%$ & \\
\hline
\end{tabular}

The overall result shows that the outstanding teachers' understanding of the competition held was still low as it stands at only $64 \%$, while the other $36 \%$ of them did not have an understanding of the competition. The figure is understandable as most of the outstanding teachers work mostly by their own personal interests and initiative.

\section{A. Leadership}

The outstanding teacher's competition involves some parties starting from national-level leadership from the Ministry of Education and Culture, the Province Educational Office, The Regencies/Mayoralties Educational Office, District and Sub District Educational Office, and School Headmasters leaderships. The national outstanding teacher's competition varies among stakeholders involved in the program. Malcolm
Baldrige model is focusing on examining how the senior executive guides the organization and how the organization handles its responsibilities to the public and practices good citizenship.

At the national outstanding teacher's competition, the involvement of the leaders participates differently. In the national context, the program has been added into the annual program as a tool in developing the quality of teachers and a whole the quality of education and also developing a teacher's career and pride. While at the provincial and mayoralties levels, the outstanding teacher's competition has not become their first priority as it, they believe, doesn't provide an impact on the development of the education.

When it comes up to the school's leadership, there are also some different results in which the headmasters having experience in the competition can provide good governance how to participate successfully in the competition while for those without sound experience in the competition, and it is the dominant number, the success of the participation depends much on the active activities of the candidates.

\section{TABLE III. LEADERSHIP COMPONENTS}

\begin{tabular}{|l|l|l|l|l|l|}
\hline Sub Components & SD & D & U & A & SA \\
\hline $\begin{array}{l}\text { I know my organization's mission (what } \\
\text { it is trying to accomplish) }\end{array}$ & 0 & 0 & 0 & 71 & 29 \\
\hline $\begin{array}{l}\text { I know my organization's vision (where } \\
\text { it is trying to go in the future) }\end{array}$ & 0 & 0 & 0 & 57 & 43 \\
\hline $\begin{array}{l}\text { My senior (top) leaders are ethical and } \\
\text { demonstrate our organization's values. }\end{array}$ & 0 & 29 & 28 & 43 & 0 \\
\hline $\begin{array}{l}\text { My senior leaders create a work } \\
\text { environment that helps me do my job }\end{array}$ & 0 & 0 & 14 & 43 & 43 \\
\hline $\begin{array}{l}\text { My senior leaders create a work } \\
\text { environment that helps me do my job. }\end{array}$ & 0 & 0 & 14 & 57 & 29 \\
\hline My organization asks what I think. & 0 & 29 & 43 & 29 & 0 \\
\hline OVERALL & $\mathbf{0}$ & $\mathbf{2 9}$ & $\mathbf{2 6}$ & $\mathbf{2 9}$ & $\mathbf{1 8}$ \\
\cline { 2 - 7 } & $\mathbf{5 5 \%}$ & & $\mathbf{4 5 \%}$ \\
\hline
\end{tabular}

Table 3 shows that the ones winning the competition is much influenced by the leadership guidance, especially those at the very low level, such as district and sub-district levels, as they are closer to the candidates. The results also show that related to the Malcolm Baldrige model, there needs comprehensive leadership guidance so that the candidates are confident, and it can become their psychological supports for them. The overall result shows that the role of the leadership in the program stands at only $47 \%$, while the other $53 \%$ think that the role of leaders and leadership on this program is still unsupportive.

\section{B. Strategic Planning}

Comparing those of Malcolm Baldrige model in strategic planning in which the model focuses on examining how the organization sets strategic directions and how it determines key action plans. The outstanding teacher's competition is started with the strategic planning in which the program has bold aims to develop and enhance teachers' competency and create society's perception of teachers. The strategic planning on 
selecting outstanding teachers doesn't lay on the selection processes until finding the best ones, but the competition shall provide a brand image to those selected and the schools where the candidates come from.

The other strategic aims of the selection of the outstanding teachers are to motivate other teachers of their professions. It promotes the importance of the teachers' profession in developing and helping Indonesia compete with other nations. The more quality teachers resulted from the competition will mean the more quality schools and quality students. If it were spread massively, the competition should have great impacts on the development of the nation, namely Indonesia.

TABLE IV. STRATEgIC PlanNING COMPONENTS

\begin{tabular}{|l|l|l|l|l|l|}
\hline \multicolumn{1}{|c|}{ Components } & SD & D & U & A & SA \\
\hline My organization as for my ideas & 0 & 71 & 29 & 0 & 0 \\
\hline $\begin{array}{l}\text { My organization encourages totally new } \\
\text { ideas }\end{array}$ & 0 & 43 & 43 & 14 & 0 \\
\hline $\begin{array}{l}\text { I know the parts of my organization's } \\
\text { plan that will affect me and my work }\end{array}$ & 0 & 43 & 43 & 14 & 0 \\
\hline $\begin{array}{l}\text { I know that my work is a part of the } \\
\text { group plan }\end{array}$ & 0 & 0 & 0 & 71 & 29 \\
\hline $\begin{array}{l}\text { The program was disseminated by the } \\
\text { Educational Regional Office }\end{array}$ & 0 & 0 & 14 & 57 & 29 \\
\hline $\begin{array}{l}\text { The education Regional Office was } \\
\text { flexible and made changes quickly when } \\
\text { needed }\end{array}$ & 0 & 14 & 43 & 43 & 0 \\
\hline OVERALL & $\mathbf{0}$ & $\mathbf{3 4}$ & $\mathbf{3 2}$ & $\mathbf{2 8}$ & $\mathbf{6}$ \\
\cline { 2 - 8 } & $\mathbf{6 6 \%}$ & & $\mathbf{3 4 \%}$ \\
\hline
\end{tabular}

Table 4 shows that only a small percentage $(34 \%)$ of the candidates understand the whole strategic planning of the outstanding teacher's competition. The biggest challenges on the issues are the willingness of the organization, the Educational Regional Offices, in accepting new ideas, and encourage ideas from the candidates as a part of the competition process. It shows about $86 \%$ of candidates think that they are only a part of the competition but not a part of ideas developed in making the program successful in the long period.

\section{Customer and Market Focus}

Customer and market focus on education is something the rarely discussed and promoted, but it grows by the time in which the educational sectors now see the customers; parents, students, and society, as the main focus on the services. The outstanding teacher's competition is thoroughly answering how educational stakeholders understand their rights of services provided by educational institutions. One of the services is the educational institutions provide quality teachers.

The outstanding teacher's competition has contributed to the development of quality teaching and learning. The competition has resulted in new approaches in the teaching and learning processes. The competition can make candidates be more creative and innovative in delivering new approaches. The competition has also contributed to the awareness of the customers in asking more about educational institution services quality. The one that is only taken for granted is the teacher's quality. The parents, students, and society can not complain about who their teachers are when entering schools. The competition will ensure schools of providing the best teaching and learning services as the game doesn't happen in a short period. It is a long process until the schools can promote candidates from their institutions.

\section{TABLE V. CUSTOMER FocUs}

\begin{tabular}{|l|l|l|l|l|l|}
\hline \multicolumn{1}{|c|}{ Components } & SD & D & U & A & SA \\
\hline $\begin{array}{l}\text { I know who my most important } \\
\text { customers/stakeholders are }\end{array}$ & 0 & 0 & 0 & 57 & 43 \\
\hline $\begin{array}{l}\text { I regularly my } \\
\text { customers/stakeholders why they need } \\
\text { and want from the teachers }\end{array}$ & 0 & 14 & 29 & 57 & 0 \\
\hline $\begin{array}{l}\text { I ask if my customers/stakeholders are } \\
\text { satisfied or dissatisfied with my work }\end{array}$ & 0 & 0 & 43 & 57 & 0 \\
\hline $\begin{array}{l}\text { I am allowed to make the decision to } \\
\text { satisfy my customers/stakeholders }\end{array}$ & 0 & 0 & 29 & 57 & 13 \\
\hline $\begin{array}{l}\text { I also know who my most important } \\
\text { stakeholders are }\end{array}$ & 0 & 0 & 29 & 71 & 0 \\
\hline OVERALL & $\mathbf{0}$ & $\mathbf{3}$ & $\mathbf{2 6}$ & $\mathbf{6 0}$ & $\mathbf{1 1}$ \\
\cline { 2 - 7 } & $\mathbf{2 9 \%}$ & & $\mathbf{7 1 \%}$ \\
\hline
\end{tabular}

Based on table 5, on the stakeholders/customers' focus, the candidates are mostly aware that their teaching quality determines the quality of the students. That's why their participation in the competition is to achieve the whole education quality. The result shows that $71 \%$ of the candidates understand the customers and stakeholders they are taking care of. The weakest percentage $(57 \%)$ lies in their regular awareness of the needs and wants of the customers/stakeholders.

\section{Measurement, Analysis and Knowledge Management}

It is clear that the outstanding teacher's competition has some parts of the analysis. In the measurement processes, for instance, there are some steps that must be passed by the candidates. The first stage of the competition is at the school in which the school will decide whose teachers have sound knowledge and competencies in following the competition. Once it has finished, the candidates shall prepare the portfolio and teaching process videos relating to their activities as teachers.

The process of assessing the portfolio shall involve the school headmasters, where the teachers serve. The aspects assessed on the portfolio include the participation of the candidates as presenters at the public training and development and scientific forum, planning and implementing the teaching and learning processes, performance appraisal from the superior, academic performance, academic works on the professional development and membership of associationrelated profession.

The candidates then make the teaching and learning videos that show his/her real activities in the classroom and involvement with his/her children. Through this, the quality of 
the candidates can be assessed better and more comprehensive as it will show the ability of the candidates in doing and implementing the teaching quality. The candidates shall also write a scientific paper related to his/her profession in which paper will be presented before the panel that will score the candidates. The following is a written test which covers the four teachers competencies namely pedagogic, social, personalities and professional.

TABLE VI. MEASUREMENT

\begin{tabular}{|l|l|l|l|l|l|}
\hline \multicolumn{1}{|c|}{ Sub Components } & SD & D & U & A & SA \\
\hline $\begin{array}{l}\text { I know how to measure the quality of } \\
\text { my work }\end{array}$ & 0 & 0 & 14 & 72 & 14 \\
\hline $\begin{array}{l}\text { I can use this information to make } \\
\text { changes that will improve my work }\end{array}$ & 0 & 0 & 14 & 72 & 14 \\
\hline $\begin{array}{l}\text { I know how the measures I use in my } \\
\text { work fit into the organization's overall } \\
\text { measures of improvement }\end{array}$ & 0 & 0 & 29 & 71 & 0 \\
\hline $\begin{array}{l}\text { I get all the important information I need } \\
\text { to do my work }\end{array}$ & 0 & 0 & 43 & 57 & 0 \\
\hline $\begin{array}{l}\text { I know how my organization as a whole } \\
\text { is doing }\end{array}$ & 0 & 0 & 29 & 43 & 28 \\
\hline OVERALL & $\mathbf{0}$ & $\mathbf{0}$ & $\mathbf{2 6}$ & $\mathbf{6 3}$ & $\mathbf{1 1}$ \\
\cline { 2 - 7 } & $\mathbf{2 6 \%}$ & & $\mathbf{7 4 \%}$ \\
\hline
\end{tabular}

Table 6 found out that most sub-components of the measurement model stand at more than $70 \%$, which means that the candidates know how to measure their job as an outstanding teacher. The lowest percentages $(57 \%)$ lies at the information lack provided by the authorities regarding their jobs.

\section{E. Human Resources Focus}

The related human resources involving in the process of selecting outstanding teachers vary from The ministry, The Provincial and Regency Educational Offices, District and Sub District educational offices, and the headmasters of the assigned schools. The outstanding candidates can not absolutely work alone without the support of the supporting regional offices in developing their knowledge, skills, and capabilities. On the outstanding teacher's competition, the candidates shall be the ones with sound knowledge on teaching and learning.

The supporting offices in the development of teacher's knowledge, skills and abilities provide activities such as seminars, workshops, peer teaching and conferences. Those activites will give the candidates opportunities to keep updating the newest information and skills. The activities also provide opportunities for the candidates to promote themselves in wider educational environments. Through the activities the candidates can participate as the presenters of the seminars, workshop and also conferences so that their thought on certain topics of the teaching and learning can be spread well.
TABLE VII. HUMAN RESOURCES COMPONENT

\begin{tabular}{|l|l|l|l|l|l|}
\hline \multicolumn{1}{|c|}{ Sub Components } & SD & D & U & A & SA \\
\hline $\begin{array}{l}\text { The people I work with cooperate and } \\
\text { work as a team }\end{array}$ & 0 & 0 & 14 & 72 & 14 \\
\hline $\begin{array}{l}\text { My bosses encourage me to develop my } \\
\text { job skills so I can advances in my career }\end{array}$ & 0 & 0 & 14 & 72 & 14 \\
\hline I am recognized for my work & 0 & 0 & 0 & 72 & 28 \\
\hline I have a safe workplace & 0 & 0 & 14 & 57 & 29 \\
\hline $\begin{array}{l}\text { My bosses and my organization care } \\
\text { about me }\end{array}$ & 13 & 29 & 29 & 29 & 0 \\
\hline $\begin{array}{l}\text { I am committed to my organization's } \\
\text { success }\end{array}$ & 0 & 0 & 29 & 71 & 0 \\
\hline OVERALL & $\mathbf{2}$ & $\mathbf{5}$ & $\mathbf{1 7}$ & $\mathbf{6 2}$ & $\mathbf{1 4}$ \\
\cline { 2 - 7 } & $\mathbf{2 4 \%}$ & & $\mathbf{7 6 \%}$ \\
\hline
\end{tabular}

Based on table 7, at the components of the Human resource, the candidates view them as positive. It can be seen from the figure that the overall number stands at $76 \%$ on the human resources perspectives. The lowest sub-component lies at how the bosses, the regional educational offices, and the subdistricts develop a model in providing care to those involved in the outstanding teacher's competition. The care is really needed as they are about competing with other qualified teachers from different regions. It means that psychological support and care are the most important factors in making the candidates gain confidence.

\section{F. Process Management}

In process management, Malcolm Baldrige's model focuses on examining aspects of how key production/delivery and support processes are designed, managed, and improved. In the national competition for outstanding teachers, there are certain event principles such as 1) competitive, which means that the national competition for outstanding teachers was based on competitive selection from all level organizations starting from school, sub-districts, districts, majorities and national levels.; 2) Objectives, the activities of selecting outstanding national teachers from all levels are carried out objectively, meaning that the competitions are conducted without discrimination, fairness and in line with certain standards; 3) Transparent; the process is based on providing opportunities for all stakeholders to gain access to information on assessments and decisions on outstanding teachers at all levels of the organization as an input, process and outcome system; 4) The assessment and decision on outstanding teachers can be accountable to all stakeholders in the education sector.

TABLE VIII. OPERATION

\begin{tabular}{|l|l|l|l|l|l|}
\hline Sub Components & SD & D & U & A & SA \\
\hline I can get everything I need to do my job & 0 & 0 & 29 & 57 & 14 \\
\hline $\begin{array}{l}\text { We have good processes for doing our } \\
\text { work }\end{array}$ & 14 & 43 & 29 & 14 & 0 \\
\hline $\begin{array}{l}\text { I can improve my work processes when } \\
\text { necessary }\end{array}$ & 0 & 0 & 14 & 57 & 29 \\
\hline $\begin{array}{l}\text { We are prepared to handle an } \\
\text { emergency }\end{array}$ & 0 & 0 & 14 & 57 & 29 \\
\hline OVERALL & $\mathbf{4}$ & $\mathbf{1 1}$ & $\mathbf{2 2}$ & $\mathbf{4 6}$ & $\mathbf{1 7}$ \\
\cline { 2 - 8 } & $\mathbf{3 7 \%}$ & & $\mathbf{6 3 \%}$ & \multicolumn{3}{l}{} \\
\hline
\end{tabular}


Table 8 shows that these components are the second-lowest component after strategic planning, which is only 63 percent, meaning that there are jobs to be done to make the program run better. Only 14 percent of the candidate's opinion is the lowest sub-component that the related offices have good processes in making the candidacy of outstanding teachers competition. The opportunity to operate better is by creating a step- by - step model on how the candidates can easily follow.

\section{G. Result of the Malcolm Baldrige Model}

The table 9 shows that the candidates don't believe in the result fo what they are doing. The lowest sub-component lies in the belief that the educational offices have the right people and skills to do its works, which stand at only $14 \%$. It confirms that they are dissatisfied with the services and support provided by the educational regional office staff. The second-lowest figure lies at their belief that their customers or stakeholders are satisfied with their services as outstanding teachers who stand at only $29 \%$.

TABLE IX. Result of THE MALCOLM BALdRIGE MODEL

\begin{tabular}{|l|l|l|l|l|l|}
\hline Sub Components & SD & D & U & A & SA \\
\hline My work services meet all requirements & 0 & 0 & 29 & 42 & 29 \\
\hline $\begin{array}{l}\text { My customers are satisfied with my } \\
\text { work }\end{array}$ & 13 & 29 & 29 & 29 & 0 \\
\hline $\begin{array}{l}\text { My organization has the right people } \\
\text { and skills to do its works }\end{array}$ & 14 & 29 & 43 & 14 & 0 \\
\hline $\begin{array}{l}\text { My organization removes things that get } \\
\text { n the ways of progress }\end{array}$ & 0 & 14 & 29 & 43 & 14 \\
\hline $\begin{array}{l}\text { My organizations obey law and } \\
\text { regulations }\end{array}$ & 0 & 14 & 29 & 43 & 14 \\
\hline $\begin{array}{l}\text { My organization practices high } \\
\text { standards and ethics }\end{array}$ & 0 & 0 & 29 & 57 & 14 \\
\hline OVERALL & $\mathbf{1}$ & $\mathbf{1 1}$ & $\mathbf{2 4}$ & $\mathbf{5 0}$ & $\mathbf{1 4}$ \\
\cline { 2 - 3 } & $\mathbf{3 6 \%}$ & & $\mathbf{6 4 \%}$ & \\
\hline
\end{tabular}

\section{DISCUSSION}

Assessing the program using the Malcolm Baldrige model is not easy and straightforward as the model is intended to assess the organization's performance when compared to those in the same industries [11]. But when talking about the program, there is not an exactly similar program that can be taken as a comparison as the model is intended to assess the whole organization operation [12,13]. The assessment using Malcolm Baldrige on the program is a new thing that would bring another program to be assessed using this tool. The tool is actually can comply with the program evaluation also.

From the perspective of leadership when it was compared between the program and performance excellence, it is a bit big gap in which not all levels within the organization understand and care with the outstanding teacher's competition itself. If they are aware, it is only caused by their job obligation in assuring the program runs well. While from strategic management, the program has followed what they call strategic planning and strategic implementation as needed to run the program within the organization $[14,15]$. The concept of "customer focus" means meeting current and potential customers' needs and expectations by developing a comprehensive understanding of customer needs and then delivering perceived value to the customer. Customer focus "is a core element of the design, manufacturing, marketing, and service processes, and it begins with finding the "voice of the customer" [16]. Service quality, from a" customer focus "point of view, is an expectation based on Customers comparing perceived results with expected service and determines its satisfaction with service quality [17]. At the customer and market focus perspective, the program has provided a comprehensive answer for the development of teaching and learning processes [18]. It has also been developed on the perspectives of satisfaction of its customers; students, parents, and society.

The term "Knowledge Management" has been applied to a comprehensive spectrum of activities aimed at managing, exchanging, and creating or enhancing intellectual assets within an organization. There is no broad agreement as to what $\mathrm{KM}$ is [19]. The three pillars provide the basis for a knowledge-based strategic management orientation, namely; 1) Methodical integration seeks to integrate human and systemsoriented KM practices into knowledge-intensive work processes in such a way that it positively affects organizational performance in terms of quality, productivity, and innovation gain. Some of the standard practices in this area are humanoriented practices, including methods such as community practice, job rotation, coaching, mentoring, post-action reviews, and storytelling; 2) Procedural integration aims to integrate $\mathrm{KM}$ into business processes throughout the organization's value chain so that it becomes an integral part of intra-organizational and inter-organizational workflows. Such practices usually lie in implementing sustainable business processes, reducing processing time, and avoiding job redundancy; 3) Organizational integration efforts to integrate $\mathrm{KM}$ into the organizational structure and facilitate dedicated management of the organization's knowledge base. Some of the common approaches applied in this field are centralization, decentralization, and primary responsibility (e.g., revenue, costs, profits, investment) [20]. The development of superior program competition knowledge management has been developed in various ways, both workshops, seminars, and conferences. It follows knowledge management theory where the development should include the things mentioned above.

Over the past 20 years, there has been a growing interest in the influence of human resource management systems (HRM) on organizational performance and employee performance outcomes, particularly on the aspect of employee welfare [21]. Organizations face two fundamental problems in the management of their human resources. The first, regarding the provision of human resources. Second, to consider the transformation of the resources obtained into work performance. The organization's training and development can have an effect that facilitates or hinders the transformation of human resources into job performance.

Such distinctions were made between the organizational effects of outreach, legitimacy, social integration, non- 
conformity, and the formation of internal vulnerabilities, and these are discussed separately [22]. These skills are used to refer to various personal qualities, attitudes, dispositions, and competencies. Many of these are described more accurately than the word "skills," where the word is omitted because it is almost useless in all content. It becomes insignificant more than what individual employers want $[23,24]$.

The outstanding teacher's competition has once provided the needs of human resources within the period, but the model of assessing the candidate must have followed the development of the society in which more and more millennials generation enter the teacher's profession. One of them because of the technology, which can ease them in doing the profession [23,25-29]. Business processes of public administrations (PAs) are often described in the form of written procedures or operational manuals. It is hoped that the description of this business process can be properly understood and applied by civil servants, who must provide legal service provisions to citizens. However, process descriptions in PA are sometimes difficult to read, ambiguous, or unclear, leading to incorrect interpretation or even wrong process execution [30-32].

Management systems (SM) positively affect organizational content management inefficiency, collaboration, and compliance. It also provides evidence that the use of management systems alone has no impact on the organization but needs to be moderated either by SM's impact on users or SM user satisfaction [33]. The outstanding competition program for teachers is also part of the public administration in which the fund used is the one taken from the people taxes so that the use of money follows the practices of public administration. The practices have also followed the good management of the system in which all candidates are to follow the central government guidance. That shows the teachers' outstanding competition was in line with the good management model.

The link between the provision of education and its objective can be partly identified through analyzing the impact of education inputs on outputs and outcomes. Teachers constitute one of the main inputs in any education system. However, of most importance is the quality of teachers, which is improved by pre- and in-service training in addition to academic qualifications [34,35]. It can be confirmed that the result of outstanding teachers' competition is the development of the quality of the teachers who finally can enhance the development of the quality of the students. The quality of the students will finally result in the quality of human resources. If it happens, in a long period, Indonesia can compete with other nations.

\section{CONCLUSION}

In the current environment, if you stand still, you fall behind. Making the right decisions at the right time is very important. Following up on decisions is challenging: implementing a strategy is much more complex than developing a strategy. If the implementation is so hard, will this teacher achievement competition program progress. And we can know that there is some progress in the processes of exceptional teachers' competition.

The program analysis using Malcolm Baldrige's model can be seen as a sound and comprehensive study that will enhance the betterment of the continuity of the program. It will also help relevant parties to focus their improvement and communication efforts on the most critical areas. They can also help you identify some ideas for improvement and identify opportunities for future program innovation.

\section{REFERENCES}

[1] N. Sorensen, "Improvisation and teacher expertise: implications for the professional development of outstanding teachers," Prof. Dev. Educ. vol. 43, no. 1, pp. 6-22, 2017

[2] A. Schleicher, "PISA 2018: Insights and Interpretations," OECD Rep. 2018, 2018

[3] S. Aydın and C. Kahraman, "Evaluation of firms applying to Malcolm Baldrige National Quality Award: a modified fuzzy AHP method,' Complex Intell. Syst., vol. 5, no. 1, pp. 53-63, 2019.

[4] T. Yang and C. Hsieh, "Six-Sigma project selection using national quality award criteria and Delphi fuzzy multiple criteria decisionmaking method," Expert Syst. Appl., vol. 36, no. 4, pp. 7594-7603, 2009.

[5] F. Tseng, Y. Chiu, and J. Chen, "Measuring business performance in the high-tech manufacturing industry: A case study of Taiwan' $\mathrm{s}$ largesized TFT-LCD panel companies ”, Internatrional J. Manag. Sci., vol. 37, pp. 686-697, 2009.

[6] M. Walpole and R.J. Noeth, "The Promise of Baldrige for K - 12 Education," ACT Policy Rep., 2002.

[7] J. Miles, B. Matthew, A.M. Huberman, and J. Saldana, Qualitative Data Analysis: A Methods Sourcebook. Los Angeles, USA: Sage Publication, 2014

[8] J.C. Creswell, Educational Reserach; Planning, Conducting and Evaluating Quantitative and Qualitative Research. Upper Saddle River, NJ: Prentice Hall, 2012

[9] R.C. Bogdan and S.K. Biklen, Qualitative Research for Education An Introduction to Theory and Methods, 5th ed. Boston: Pearson Education, 2007

[10] T.C. Foster, J.K. Johnson, E.C. Nelson, and P.B. Batalden, "Using a Malcolm Baldrige framework to understand high- performing clinical microsystems," BMJ Quality \& Safety, vol. 16, no. (5), pp. 334-342, 2007.

[11] Baldrige, "Are We Making Progress? How d," Baldrige Perform. Excell. Progr., vol. 1, no. 1, p. 4, 2019.

[12] A. Arroio, "IS MEDIA LITERACY AN URGENT ISSUE IN EDUCATION FOR ALL?," Problems of Education in the 21st Century, vol. 75, no. 5, pp. 416-418, 2017.

[13] C. Lin and C. Su, "The Taiwan national quality award and market value of the firms : An empirical study," Intern. J. Prod. Econ., vol. 144, no. 1, pp. 57-67, 2013.

[14] F.R. David, Strategic Management CONCEPTS AND CASES, 13th ed. New Jersey: Pearson Education Inc, 2011.

[15] A.W. Steiss, Strategic management for public and nonprofit organizations. Routledge, 2003.

[16] A.J. Ganimian and R.J. Murnane, "Improving Education in Developing Countries: Lessons From Rigorous Impact Evaluations," Rev. Educ. Res., vol. 86, no. 3, pp. 719-755, 2016. 
[17] L. Martin, "The Assessment of Learning Outcomes in Australia : Finding the Holy Grail," AERA Open, vol. 3, no. 1, pp. 1-19, 2017.

[18] C. McCaig, "The retreat from widening participation? The National Scholarship Programme and new access agreements in English higher education," Stud. High. Educ., vol. 41, no. 2, pp. 215-230, 2016.

[19] R.O. Shannak, "Measuring knowledge management performance," Eur. J. Sci. Res., vol. 35, no. 2, pp. 242-253, 2009.

[20] G. Turner and C. Minonne, "Measuring the effects of knowledge management practices Measuring the Effects of Knowledge Management Practices," Electron. J. Knowl. Manag., vol. 8, no. 1, 2010.

[21] R. Peccei and K. Van De Voorde, "Human resource management - wellbeing - performance research revisited : Past , present , and future," Human, no. April, pp. 1-25, 2019.

[22] O. Nordhaug, "HUMAN RESOURCE PROVISION AND," J. Hum. Resour. Manag., vol. 2, no. 3, pp. 17-26, 20172.

[23] I. Grugulis, "Skills, Training and Human Resource Development: a Critical,” Hum. Resour. Manag. J., vol. 17, no. 3, pp. 307-308, 2007.

[24] J. Heyes and M. Stuart, "Does Training Matter? Employee Experiences and Attitudes," Hum. Resour. Manag. J., vol. 6, no. 3, pp. 7-21, 1996.

[25] R.R. Aliyyah, M.A. Humaira, D. Mulyadi, and S.W. Ulfah, "Acquiring And Developing Outstanding Teachers Candidate: A Comparative Study From State And Private Elementary School," Int. J. Sci. Technol. Res., vol. 8, no. 11, pp. 1843-1847, 2019.

[26] R.R. Aliyyah, D. Mulyadi, Rasmitadila, S.W. Ulfah, and M.A. Humaira, "Outstanding Teachers', Competition: Between Strategies and Challenges," Adv. Soc. Sci. Educ. Humanit. Res., vol. 400, no. Icream 2019, pp. 153-157, 2020.

[27] R.R. Aliyyah, W. Widyasari, R. Rasmitadila, M.A. Humaira, S.W. Ulfah, and D. Mulyadi, "Outstanding Teachers: The Steps In Acquiring Them,” Int. J. Educ. Vocat. Stud., vol. 1, no. 5, pp. 440-447, 2019.
[28] R.R. Aliyyah, Megan Asri Humaira, Sri Wahyuni et all "Outstanding Teacher: Strengthening Education in The Era of Industrial Revolution 4.0," J. Sos. Hum., vol. 11, no. April, pp. 59-64, 2020.

[29] R.R. Aliyyah, D. Mulyadi, Widyasari, et al "Guru Berprestasi Sumber Daya Manusia Pengembang Mutu Pendidikan Indonesia," Alignment J. Adm. Educ. Manag., vol. 2, pp. 157-165, 2019.

[30] R.R. Aliyyah, S.P. Fauziah, Rasmitadila, et al "Outstanding teacher model assistance: effective steps to be competitive human resources," Int. J. Adv. Sci. Technol., vol. 29, no. 7, pp. 3255-3262, 2020.

[31] R.R. Aliyyah, Rasmitadila, M.A. Humaira, et al "Are The Assessment Criteria and The Role of Educational Stakeholders Able to Make Outstanding Teacher?," Int. J. Psychosoc. Rehabil., vol. 24, no. 6, pp. 8946-8957, 2020.

[32] A. Ferrari, H. Friedrich, G. Oronizo, and S. Gnesi, "Improving the Quality of Business Process Descriptions of Public Administrations: Resources and Research Challenges," Bus. Process Manag. J., vol. 12, 2016.

[33] A. Harr, J. vom Brocke, and N. Urbach, "Evaluating the individual and organizational impact of enterprise content management systems," Bus. Process Manag. J., vol. 25, no. 7, pp. 1413-1440, 2019.

[34] R.R. Aliyyah, U. Rosyidi and Rugaiyah, "Higher Education Scholarship: Gate To Develop Educational Human Resource Quality," Int. J. Educ. Vocat. Stud., vol. 1, no. 4, pp. 349-358, 2019.

[35] M. Ngware, E. Onsomu, and M. Damiano, Impact of primary school education inputs on outputs in Kenya : Empirical Impact of Primary School Education Inputs and Outputs in Kenya: Empirical Evidence Moses Ngware Kenya Institute for Public Policy, vol. 1, no. January 2007. 2016. 